\title{
An Analysis of the Impact of Foreign Investment on Regional Disparities: A Case of Malaysia
}

\author{
Hasnah $\mathrm{Ali}^{1}$, A. C. Er ${ }^{3}$, A. R. Ahmad ${ }^{2}$, N. Lyndon ${ }^{3}$ \& Sanep Ahmad ${ }^{1}$ \\ ${ }^{1}$ School of Economics, Faculty of Economics and Management, Universiti Kebangsaan Malaysia, Bangi, \\ Malaysia \\ ${ }^{2}$ Faculty of Plantations and Agro Technology, University Technology Mara, Shah Alam, Malaysia \\ ${ }^{3}$ School of Social, Development and Environment, Faculty of Social Sciences and Humanities, Universiti \\ Kebangsaan Malaysia, Bangi, Malaysia \\ Correspondence: Hasnah Ali, School of Economics, Faculty of Economics and Management, Universiti \\ Kebangsaan Malaysia, 43600 Bangi, Selangor, Malaysia. E-mail: hasnah@ukm.my
}

Received: July 22, 2013 Accepted: September 1, 2013 Online Published: October 11, 2013

doi:10.5539/ass.v9n14p7 URL: http://dx.doi.org/10.5539/ass.v9n14p7

\begin{abstract}
Foreign Direct Investment (FDI) is said to boost the economic growth of the host country and FDI also is one of the factors that contribute to regional disparities because FDI typically tend to focus on the areas that offer economic advantages compared to those areas of backward regions. This study aimed to investigate the effect of FDI on economic development and regional disparities in a globalizing economy of Malaysia. It explores the proposition that regional disparities are linked to the FDI that come into the country. This study involved six areas of the Northern, Central, Eastern, Southern, Sabah and Sarawak Regions. The variables used involved data acquired from Bank Negara Malaysia Report, Ninth Malaysia Plan, Tenth Malaysia Plan, Labor Investigation Report, Department Of Statistics Malaysia, Malaysian Investment Development Authority (MIDA) and Economic Planning Unit (EPU) and the period covered was 28 years ranging from the year of 1980 to 2008 . The analysis was conducted using classical production function which explained output as function to capital and labor and involved time series and cross section data which will be regressed with Least Square Dummy Variables (LSDV) Regression Model and Random Effects Model. It was found that FDI is positive and significantly related to GDP implying that FDI is enhancing economic growth and regions with higher level of FDI tend to have higher GDP. Since FDI focuses on the developed areas especially the central, northern and southern regions, thus this concentration will widen the regional disparities in Malaysia. These disparities has brought about the imbalances between the society with regards to poverty, manufacturing activities and many more.
\end{abstract}

Keywords: economic development, regional disparities, foreign direct investment

\section{Introduction}

Foreign direct investment (FDI) has grown dramatically as a major form of international capital transfer over the past decades. It has become a major form of net international burrowing for Japan and the United States of America (the world's largest international lender and borrower respectively) (Frost, 1993). FDI also had contributed much to the development of many developing countries (Athukorala \& Menon, 1996; Aoki, 1992). It is said that the entrance of FDI to one country allegedly will encourage more economic growth and cause positive impact on that country's progresses. However, some study found that this FDI is also one of the factors which could contribute to disparities between one region to another. This is because FDI is usually more concentrate to an area which offers economic advantages that have low production cost especially in regions which are more developed. The growth effects of FDI may be constrained by the concentration of FDI in relatively advanced locations (Aggarwal, 2005).

One of the advantages of foreign direct investment is that it helps in the economic development of the particular country where the investment is being made. This is especially applicable for developing economies. During the 1990s, foreign direct investment was one of the major external sources of financing for most countries that were growing economically. It has also been noted that foreign direct investment has helped several countries when 
they faced economic hardship (Economy Watch, 2010).

During the last fifty years, the government of Malaysia, through a series of five-year development plans has implemented various policies and programs aimed at alleviating regional disparities and underdevelopment. The purpose of the regional development in Malaysia was to mainly focus on reducing the large imbalances in social and economic development among states in the country. To correct these imbalances is important because according to Hill (2002), regional economic disparities hamper economic growth and that countries with a relatively even spatial distribution of income are likely to grow faster. A whole series of factors are responsible for the existence of regional inequalities. Among them may include labor migration, capital migration, trade, interregional linkages, the 'non-economic factors' and the central government policy.

Regional disparities as mentioned can be caused by many factors. Nevertheless FDI which has played very important role in the shaping of the economy of many developing countries (Athukorala \& Menon, 1996) has to be analyzed. This study therefore aimed to investigate the effect of FDI on economic development and regional disparities in a globalizing economy of Malaysia.

\section{Literature Review}

Theoretically, regional disparities can be caused by various factors, such as geographic differences, endowment factors (eg, physical capital and human capital), factor productivity and regional development strategies. Overall, any factors that could lead to regional differences in terms of economic growth may also play a role in the regional income disparity. How then FDI can be involved in this scene? This is because FDI is often seen as a key factor leading to the success in the revenue growth in most developing countries (UNCTAD, 2003). Does FDI generate a host country's economy towards a more equitable or whether it actually causes the rich to be rich and the poor becoming poor? It is especially important for its potential to transfer knowledge and technology, create jobs, boost overall productivity, enhance competitiveness and entrepreneurship, and ultimately eradicate poverty through economic growth and development" (UN, 2002, p. 5) However, the empirical evidence supporting this view across developing host countries of FDI is weak at (e.g. Nunnenkamp, 2004)). Likewise, earlier studies on India typically failed to find a robust and positive link between inward FDI and economic growth, including Agrawal (2005) and Pradhan (2002).

Holger \& Labonte (2011) however looked empirically at the implications that a country that implements new protectionist measures may expect that this may result in lower foreign direct investment inflows into the economy. Holger et al (2010) also analyzed how German firm decisions were affected by the liberalisation of FDI regulations in India.

These questions are considered extremely important because the onset of massive growth in global FDI flows during the 1990s. The views and opinions of FDI is disproportion-chain but different. There is a state that globalization is driven by FDI, and trade will widen the gap between the poor and the rich (Mazur, 2000). While the view from the other one is claiming that increased economic integration through FDI and trade for the past two decades has been to promote equality in income and reducing poverty (Dollar \& Kraay, 2002). There are many studies that have focused on evaluating the role of globalization (Aghion \& Williamson, 1998; Kaplinsky, 2000; Ram, 2003; Zhang \& Zhang, 2003) and trade (Lawrence, 1996; Cline, 1998) in income inequality.

Based on the Report of the Ninth Malaysia Plan (Malaysia, 2006), the development gap between regions can be identified by the State Development Composite Index (PFI), the Gross Domestic Product (GDP) and growth, household income and poverty rates and the attractiveness of new investment in the manufacturing sector. According to another report, the direction of investment flows were more focused on more developed states than less developed states. More developed states like Selangor, Johor, Penang and Malacca still remains a prime choice for local investors and foreign investors. For example, a total of 4807 approved manufacturing projects during the year 2001 to year 2005 valued at RM132.4 billion. A total of RM73.6 billion or 55.6 per cent are concentrated in Selangor, Johor, Penang and Malacca. The remaining 44.4 percent scattered in nine states and two other federal territories. The pattern of development such as this truly reflects the disproportion (Economic Council, February 2007; Hasnah Ali, 1992). This study was supported by Katiman Rostam $(2001 ; 2007)$ who also found that the states with competitive advantage and offer a variety of economic advantages over the location of the focus of investors, particularly foreign direct investment. Since the 1970's, he found that more developed states like Selangor have become the main investors and become more significant after 2001.

The increase in the number of projects and investment capital to more developed states, particularly the state showed a significant concentration in industrial processes in the country. The study by H.Osman-Rani (1992) is intended to describe and analyze the relationship between industrial growth, foreign investment and regional balance in the Malaysian economy. He found that the development of industrial sector in Malaysia depends 
strongly on two closely interrelated factors: Foreign Direct Investment (FDI) and industrial areas, including the Free Trade Zone (FTZ). The combination of these two factors are consistent and appropriate with the objective of government policy to create new industries in the area and a broad strategy to reduce the concentration of industry in an area and promote balanced regional development. Based on his analysis of foreign and domestic investment data on manufacturing projects approved by the government in the state between 1980-1989 is sufficient to indicate that the spread of FDI tends to result in disproportion to the broad region. At the end of the study H. Osman-Rani found that FDI became part of the problem of disproportion region than to be part of the solution to balance regional development.

Fazekas (2000), found that the distribution of FDI flows in the region was strongly influenced by the level of education for the local population, the external effects agglomerasi city and the geographical location of a region. FDI attracted to areas where unemployment rates are low and the level of good education and have a geographical advantage, which is an increase in FDI will create job opportunities more widely. The analysis also describes other foreign firms prefer to hire younger workers and workers in education. In addition, foreign firms, it is not only labor and capital more productive but also try to increase the capital-skill matching between modern technology and skilled labor (Fazekas \& Kollo, 1999). Most analysis also agree that regions with higher ratio of employment will achieve success in the labor market, but the study did not investigate the role of FDI flows in explaining differences in regional labor markets (Foti, 1995; Hunya, 1997; Hamar, 1999).

Fleisher, Li and Qiang Zhao (2005) in their study found that FDI has a strong relationship on the growth of total factor productivity (TFP), and FDI flows are also influenced by the level of infrastructure capital. Xiaolan Fu (2007), in a study that says that FDI contributed significantly towards regional innovation capacity in China in general. In addition, FDI is also positively on the efficiency of regional innovation. Increased innovation capability will contribute to further regional economic growth for the region. May Wen (2005), found that FDI flows to generate a demonstration effect in the market to identify areas for investment in fixed assets and the location of industry. In addition, it also affected the region export and earnings growth in different region in China since the second half of the 90 's, which depends on the orientation, FDI in different regions. For example, in east China, geographical advantage in exports attracted FDI flows and helps to promote exports. In contrast, the negative impact of FDI flows in the middle of China on export orientation weakens the contribution of regional income growth.

Many studies agreed that FDI has indeed contiributed towards the economic growth of many developing countries. However Nunnenkamp (2004) and Agrawal (2005) for example found that the empirical evidence supporting this view across developing host countries of FDI are weak. With regards to regional inequalities The Schumpeterian growth model presented by Aghion et al. (2006) provides an explanation why more FDI may promote growth in relatively advanced regions, while leaving growth almost unaffected in poorer regions. To date, research that focuses on the impact of FDI upsetting the inequalities of income in the host country, whether local or global level remains limited. This is especially true for Malaysia, whereby not much research in this area of regional disparities has been done. Therefore the need for this study to be done.

\section{The Study Area}

Malaysian regions in this study consist of the following six areas:

- Central Region (Selangor, Malacca and Negeri Sembilan)

- Northern Region (Kedah, Perlis, Perak and Penang)

- Eastern Region (Kelantan, Terengganu and Pahang)

- Southern Region (Johor)

- Sabah

- Sarawak 


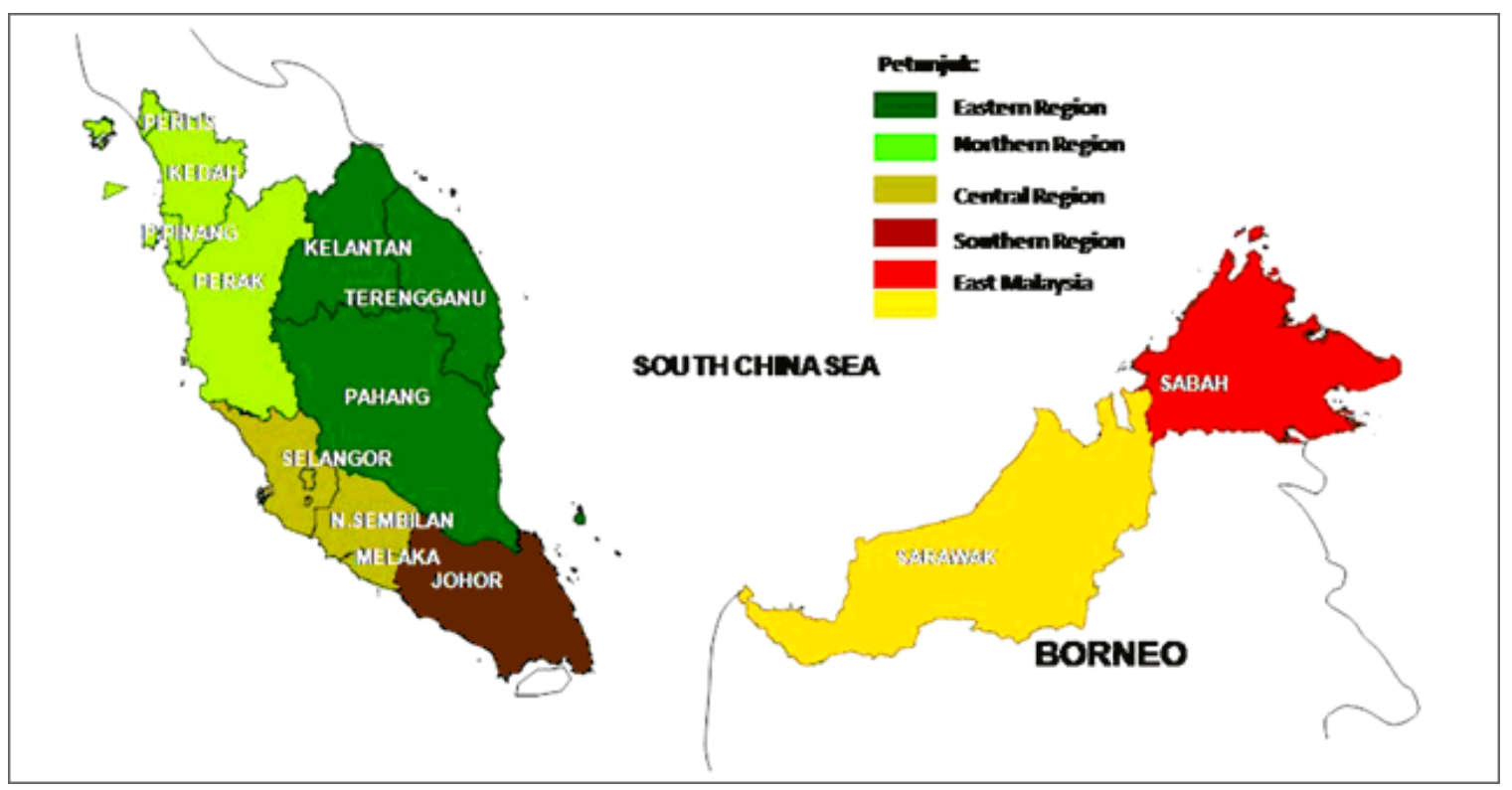

Figure 1. The regions in Malaysia

The distribution of the six regions is based on the geographical location and they also represent the different levels of economic development. In general, the regions in the east coast that is Sabah and Sarawak are underdeveloped areas compared to the states in the peninsular Malaysia. The three other areas of the central, southern and eastern regions are more prosperous. These differences in their levels of development may be due to many reasons of which FDI could be one of the main ones.

Widening the development gap between regions in Malaysia, is said to be closely related to the policies and industrial strategies implemented around the early 1970s. Especially after the federal government implemented the Free Trade Zones (FTZ) in the Federal Industrial Development Authority (FIDA) in 1971. The existence of this trade zones have attracted the interest of local investors and foreign investors to invest in industrial areas which are mostly located in more developed regions such as the Central Region.

Table 1. Summary data total employment, total domestic investment and foreign direct investment amount from 1980 to 2008

\begin{tabular}{lcccccc}
\hline Region & \multicolumn{2}{c}{$\begin{array}{c}\text { Number of } \\
\text { Employment }\end{array}$} & $\begin{array}{c}\text { Total domestic } \\
\text { investment }\end{array}$ & \multicolumn{2}{c}{$\begin{array}{c}\text { Total foreign } \\
\text { investment }\end{array}$} \\
\hline \multirow{3}{*}{ Central region } & Value & Share & Value & Share & Value & Share \\
Northern region & 845049 & 33 & $8.3414 \mathrm{E}+10$ & 31 & $9.307 \mathrm{E}+10$ & 31 \\
Eastern region & 713167 & 28 & $6.0832 \mathrm{E}+10$ & 23 & $8.708 \mathrm{E}+10$ & 29 \\
Southern region & 181933 & 7 & $4.4293 \mathrm{E}+10$ & 17 & $4.201 \mathrm{E}+10$ & 14 \\
Sabah & 534531 & 21 & $2.5055 \mathrm{E}+10$ & 9 & $5.446 \mathrm{E}+10$ & 18 \\
Sarawak & 129962 & 5 & $1.999 \mathrm{E}+10$ & 8 & $6.94 \mathrm{E}+09$ & 2 \\
Total & 135237 & 5 & $3.1747 \mathrm{E}+10$ & 12 & $1.997 \mathrm{E}+10$ & 7 \\
& $\mathbf{2 5 3 9 8 7 9}$ & $\mathbf{1 0 0}$ & $\mathbf{2 . 6 5 3 3 E}+\mathbf{1 1}$ & $\mathbf{1 0 0}$ & $\mathbf{3 . 0 3 5 E}+\mathbf{1 1}$ & $\mathbf{1 0 0}$ \\
\hline
\end{tabular}

Table 1 shows the contributions of domestic investors and foreign investors in Malaysia starting from 1980 to 2008 based on the total amount of capital investment and employment. Overall, the Central Region which consists of the states of Selangor, Federal Territory of Kuala Lumpur, Malacca and Negeri Sembilan is the largest recipient in the total domestic investment, total FDI and total employment. Northern Region is the second largest recipient of all the three aspects and was followed by the Southern Region, Eastern Region, Sarawak and finally 
the Sabah region. According to Table 1, the share of foreign direct investment, domestic investment and the total employment accepted by the Central Region for the period 1980 to 2008 was the highest recorded at 31 percent, 31 percent and 33 percent respectively.

Sabah and Sarawak were clearly left behind in every aspects with the least share of employment, domestic investment and foreign investment.

\section{Methodology}

\subsection{Research Design}

1) Sample

The data used in the empirical analysis were collected from various primary data sources such as Bank Negara Malaysia Report (BNM), Ninth Malaysia Plan (RMK-9), and Labor Investigation Report, Department Of Statistics Malaysia, Malaysian Investment Development Authority (MIDA) and Economic Planning Unit (EPU) from 1980-2008 (Malaysia 2001; Malaysia 2005a; Malaysia 2005b; Malaysia 2005c; Malaysia 2006; Malaysia 2011; MIDA 2004; MIDA 2006). The data comprised every state in the particular region with the following categories:

- Central region: States of Selangor, Melaka and Negeri Sembilan

- Northern region: States of Perlis, Kedah, Perak and Penang

- Eastern region: State of Kelantan, Terengganu and Pahang

- Southern region: States Johor only

- Sabah region: State of Sabah only

- Sarawak region: State of Sarawak only.

2) Dependent variable

KDNK

3) Independent variables

FDI

PDI

$\mathrm{L}$

\subsection{The Models}

This study will involve time series data and cross-sectional data (data panel) namely data for the 6 mentioned regions within the period of 27 years. This analysis will apply the classical production function describing the output as a function of capital and labor. The function will be estimated by applying Fixed Effects Model or Least Square Dummy Variable (LSDV) Regression Model and Random Effects Model. The basic production functions used are as follows:

$$
\operatorname{Ln}(K D N K)_{i t}=\beta_{0}+\beta_{1} \operatorname{Ln}(P D)_{i t}+\beta_{2}\left(F D I_{i t}\right)+\beta_{3} \operatorname{Ln}\left(L_{i t}\right)+\mu_{i t}
$$

Where;

$$
\begin{aligned}
& \text { KDNK = Real Gross Domestic Product } \\
& \text { PD }=\text { Domestic Investment } \\
& \text { FDI }=\text { Foreign Direct Investment } \\
& \mathrm{L}=\text { Labor (number of workers employed) } \\
& \mu=\text { Stochastic error } \\
& \text { 1) Fixed Effects Model }
\end{aligned}
$$

To measure the variation for the impact of FDI on the various regions, dummy variable (D) will be used between regions of Central, Southern, Eastern, Northern, Sarawak and the Sabah Regions. In particular Least Square Dummy Variables (LSDV) Regression Model is employed. Sarawak Region is used as the bench mark. The LSDV regression is ordinary least squares (OLS) with dummy variables. LSDV is widely used because it is relatively easy to estimate and interpret substantively. With the inclusion of dummy variable representing the various regions, the regression model would be as follows: 


$$
\begin{gathered}
L n K D N K_{i t}=\beta_{0}+\beta_{1} L n P D_{i t}+\beta_{2} L n F D I_{i t}+\beta_{3} D F D I A_{i t}+\beta_{4} D F D I B_{i t}+\beta_{5} D F D I C_{i t}+\beta_{6} D F D I D_{i t}+\beta_{7} D F D I E_{i t} \\
+\beta_{7} L n L_{i t}+\mu_{i t}
\end{gathered}
$$

With;

$D_{F D I}=1$ Central region, 0 others

$D F D I B_{i t}=1$ Northen region, 0 others

$D F D I C_{i t}=1$ Eastern Region, 0 others

$D F D I D_{i t}=1$ Southern region, 0 others

$D_{F D I E}=1$ Sabah region, 0 others

And therefore,

$\beta_{0}=$ Intercept for Sarawak Region

$\beta_{3}=$ Intercept for Central Region

$\beta_{4}=$ Intercept for Northern Region

$\beta_{5}=$ Intercept for Eastern Region

$\beta_{6}=$ Intercept for Southern Region

$\beta_{7}=$ Intercept for Sabah Region

2) Random Effects Model (REM) or Error Components Model (ECM)

the second model that will be used is Random Effects Model which is also known as Error Components Model (ECM). The specification of the model is as follow:

$$
\operatorname{Ln}(K D N K)_{i t}=\beta_{0}+v_{i t}+\beta_{1} \operatorname{Ln}(P D)_{i t}+\beta_{2}(F D I)_{i t}+\beta_{3} \operatorname{Ln}(L)_{i t}+\mu_{i t}=\beta_{0}+\beta_{1} \operatorname{Ln}(P D)_{i t}+\beta_{2}(F D I)_{i t}+\beta_{3} \operatorname{Ln}(L)_{i t}+w_{i t}
$$

Taking into account all the usual assumptions made by ECM, the above model is estimated using Generalized Least Squares (GLS)

\section{Results and Discussions}

The regression results of panel data are reported in Table 2. Model 1 correspond to None-Effect Regression Model while model 2 and model 3 correspond to Cross-Section Fixed Effects i.e least-square-dummy variable (LSDV) model and Cross-Section Random Effects Model respectively. The models are estimated using a panel of 14 states grouped into 6 regions for the period of 1980-2008. 
Table 2. Panel data regression results (Unbalanced data)

\begin{tabular}{|c|c|c|c|}
\hline & $\begin{array}{c}\text { Model } \\
\text { 1:None-Effect }\end{array}$ & $\begin{array}{c}\text { Model 2:Cross-Section Fixed } \\
\text { Effects }\end{array}$ & $\begin{array}{c}\text { Model 3:Cross- Section Random } \\
\text { Effects }\end{array}$ \\
\hline \multirow{2}{*}{$C$} & 17.23708 & 15.53675 & 17.23489 \\
\hline & $(9.920542)$ & (8.079136) & $(5.080613)$ \\
\hline \multirow{2}{*}{$L N G$} & -0.145010 & $-0.494754 * *$ & -0.011443 \\
\hline & $(-1.177218)$ & $(-2.736259)$ & $(-0.045716)$ \\
\hline \multirow{2}{*}{$L N P D$} & -0.067604 & 0.162625 & -0.180030 \\
\hline & $(-0.519047)$ & (1.204308) & $(-0.691500)$ \\
\hline \multirow{2}{*}{ LNFDI } & $0.418691 * * *$ & $0.4277503 * * *$ & $0.473855^{* *}$ \\
\hline & (3.995605) & (4.168920) & $(2.286804)$ \\
\hline DCent & - & $\begin{array}{c}0.016024 \\
(0.907078)\end{array}$ & - \\
\hline DNort & - & $\begin{array}{c}0.046476 \\
(1.058423)\end{array}$ & - \\
\hline DEast & - & $\begin{array}{l}-0.031653 * * \\
(-2.224096)\end{array}$ & - \\
\hline DSouth & - & $\begin{array}{c}0.038779 \\
(2.253383)\end{array}$ & - \\
\hline DSabah & - & $\begin{array}{c}0.046460 * * * \\
(2.765964)\end{array}$ & - \\
\hline$R^{2}$ & 0.304433 & 0.495835 & 0.136057 \\
\hline$F$ & 11.08779 & 8.729711 & 3.989572 \\
\hline$P$ & 0.000004 & 0.000000 & 0.010758 \\
\hline$D W$ & 1.060379 & 1.12055 & 1.075147 \\
\hline
\end{tabular}

Note: ${ }^{* * *}$ significance levels at 1 percent

** significance levels at 5 percent

* significance levels at 10 percent

C Constant

LNG Labor

LNPD Domestic Investment

LNFDI Foreign Direct Investment

DCent Central Region

DNort Northern Region

DEast Eastern Region

DSouth Southern Region

DSabah Sabah

R2 Regresion

F $\quad$ F-statistic

P Probability

DW Durbin Watson

To test the best model between the "fixed and random effect", we use the Haussman test (see Table 3) on the 
model of "random effect". The test results found that the null hypothesis for model "random effect" was rejected at one percent confidence level $(\mathrm{P}>0.1 \%)$. This finding shows that the regression model "fixed effect" by using the GLS is relatively good in explaining the research under review compared with model "random effect". However, Random Effects Model can also be used since it is significant at $1 \%$.

Table 3. Hausman test for random effects model

\begin{tabular}{lll}
\hline Tested model & Chi-Sq.Statistic & F Statistics \\
\hline Random Effect Model & 1.881488 & 1.734070 \\
\hline
\end{tabular}

Based on P value as shown in Table 2, Fixed Effects Model is the best followed by Non-Effects Model and Random Effect. According to Table 2, the FDI variable shows a consistent positive and significant effect on GDP For the case of Non-Effect and Fixed Effects Model, FDI is significant at $1 \%$ level of confidence effect on economic growth. But it is significant at 5\% for the case of Random Effects Model. The value of coeficient of 0.4277 imply that one per cent increase in FDI, would increase GDP by 0.43 percent. This finding is consistent with the findings obtained by Holger and Frances (1997) who found that the role of FDI has helped to improve the Irish economic growth. This study was supported by William and McLeod (1998) who also found an increase in foreign direct investment equity to GDP. Huang, Shuo (2009) also found that FDI has a positive and statistically significant impact on economic growth. It is also significant and positive relations to changes in GDP.

The important implication from the impact of positive and significant value of FDI on GDP showed that if the value of FDI is high, the GDP is also high. As such any areas that receive high FDI will lead to higher economic growth. Normally, FDI is usually focused to developed areas, especially the central, northern and southern regions, as shown in Table 1 based on the value of percentages share of FDI. It means that development in these three areas will rise higher than three other areas of the east, Sarawak and Sabah which has received a small FDI. Thus, FDI in Malaysia will increase the imbalance of regional economic growth, especially between the central, northern and southern regions compared with the others.

Domestic investment (LnPD) also shows a positive relation to GDP, but not significant. As with FDI, the disproportion in the distribution of domestic investment also contributed to regional income disparities. While total employment in local and foreign companies showed a negative significant relationship in explaining the relationship between the GDP variable. Meanwhile, domestic investment is not significant but it still has positive relationship with the GDP after considering the regional dummy variable.

The employment variable show a negative significant relationship with the region's GDP. This means increasing in labor will reduce economic growth. Therefore, the region that emphasized in labor intensive showed a low levels in development. Generally, the developed areas such as central, northern and southern regions are focus on capital intensive while the underdeveloped areas such as Sabah, Sarawak and the eastern region are more intensive in labor. This will bring a gap because the developed areas will become more developed while the underdeveloped areas will continue to decline with regards to development. Thus, the differences in capital and labor intensive industries between regions will bring more unequal development and widen the regional disparities.

Today, foreign investments in Malaysia originate from all over the world. Their range of operations have spread rapidly from plantation crops and tin smelting to finance, manufacturing and a broad range of service activities. Their scale of operations, their control of technological and marketing information and their ability to operate in foreign countries have given them a a peculiar strength in Malaysia's globalizing economic development and international relations. Broadly speaking, according to Ragendran (2002), FDI in the context of Malaysia's globalizing economy has been a relatively successful experiment.

\section{Conclusions}

Studies on the effects of FDI on regional disparities in the host country are very exciting and there was an increase in the number of empirical and theoretical research on these lately. The regression results showed that there was a strong effect of FDI on economic growth in the Central Region (DFDIA) and Southern Region (DFDID) and very weak in the Eastern Region (DFDIC), Sabah (DFDIE), and Northern Region (DFDIB). In conclusion, the investment climate in the Central Region and Southern Region, or in the Northern Region is better developed than in the backward regions such as Eastern Region, Sabah and Sarawak. Inequalities between 
the regions is something that can not be avoided during the process of economic development, particularly for developing countries. Therefore, the equality and efficiency of regional development are two major issues faced by the government. Therefore, the government should give special attention to the development of regional disparities. Ongoing efforts to diversify the economic structure of less developed regions should be implemented immediately so that the gap of imbalances between regions can be reduced.

The presence of these foreign investors and reviewing the areas that have the potential to become the industrial centers are their targets of investment and offer opportunities for local people to provide services and is involved in the industrial sector. The importance of this industry will be introduced as the commercialization of an area and be a center to communicate with other areas. Of course the presence of foreign investors will help to increase the range of utilities such as water, electricity and a central dispersion of the surrounding area. Gross domestic product of a strong and stable country to help other agencies and perhaps to open a new industry. This is because the countries involved in the war and the poor will certainly not be able to return to overseas investors to set up new industries. Meanwhile countries with low GDP would find it difficult to help the local entrepreneurs to open up industries. They are not able to provide assistance and finance the entrepreneurs to compete and started to participate in any industry.

In addition, labor intensive is likely to widen the disparities in which developed regions with capital intensive will developed faster compared to the underdeveloped regions with labor intensive.

\section{References}

Aggarwal, A. (2005). The Influence of Labor Markets on FDI: Some Empirical Explorations in Export Oriented and Domestic Market Seeking FDI across Indian States. Universiti of Delhi. Retrieved from http://knowledgeforum.tifac.org.in/IndexServer/tifac/article/22.doc

Aghion, P. R., Burgess, S. J., Redding, \& Zilibotti, F. (2006). The Unequel Effects of Liberalization: Evidence from Dismantling the Licence Raj in India. Centre for Economic Policy Research, Discussion Paper 5492. London.

Aghion, P., \& Williamson, J. G. (1998). Growth, Inequality, and Globalization: Theory, History, and Policy. Cambridge University Press.

Agrawal, P. (2005). Foreign Direct Investment in South Asia: Impact on Economic Growth and Local Investment. In E. M. Graham (Ed.), Multinationals and Foreign Investment in Economic Development (pp. 94-118). Basingstoke, Palgrave Macmillan.

Ali, H. (1991). Ekonomi Wilayah: Teori dan amalan (Regional Economics: Theory and Practice). Percetakan Dewan Bahasa dan Pustaka: Ampang, Selangor.

Cline, W. (1998). Trade and Income Distribution. Washington, DC: Institute for International Economics.

Dollar, D., \& Kraay, A. (2002). Spreading the Wealth. Foreign Affairs, 81(1), 120-133. http://dx.doi.org/10.2307/20033007

Economy Watch. (2010). Benefits of Foreign Direct Investment. New York

Fazekas, K. (2000). The impact of foreign direct investment inflows on regional labour Markets in Hungary. Budapest Working Papers.

Foti, K. (1995). Some Impacts of Foreign Direct Investment on Employment and Labor in Hungary. Budapest Institute for World Economics, Hungarian Academy of Sciences.

Fu, X. L. (2007). Foreign Direct Investment, Absorptive Capacity and Regional Innovation Capabilities: Evidence from China. Queen Elizabeth House, University of Oxford.

Görg, H., \& Labonte, P. (2011). Trade protection during the crisis: Does it deter foreign direct investment? IDEAS. Kiel Working Papers 1687, Kiel Institute for the World Economy.

Görg, H., \& Ruane, F. (1997). Reflections on Irish Industrial Policy towards Foreign Direct Investment. Economics Policy Papers 973, Trinity College Dublin, Department of Economics.

Gorg, H., Muhlen, H., \& Nunnenkamp, P. (2010). FDI Liberalisation, Firm Heterogeneity and Foreign Ownership: German Firm Decisions in Reforming India. The Journal of Development Studies, 46(8), 1367-1384. http://dx.doi.org/10.1080/00220380903318053

Gruben, W. C., \& McLeod, D. (1998). Capital Flows, Savings, and Growth in the 1990s. The Quarterly Review of Economics and Finance, 38(3), 287-301. http://dx.doi.org/10.1016/S1062-9769(99)80119-7 
Gujarati, D. N. (2003). Basic Econometrics (4th ed.). International Edition: Mc Graw-Hill, Inc.

Hamar, J. (1999, March). Regional Characteristics of Foreign Direct Investment in Hungary. Kulgazdasag, 43, 47-69.

Huang, S. (2009). Foreign Direct Investment and Regional Growth in China. Proceedings of the German Development Economics Conference. Frankfurt a.M. 2009, No. 14.

Hunya, G. (1997). Foreign Direct Investment and Its Effect in the Czech Republic, Hungary and Poland. Research Report 168. Vienna: Vienna Institute for International Economic Studies.

Kaplinsky, R. (2000). Globalization and Equalization: What Can Be Learned from Value Chain Analysis? Journal of Development Studies, 37(2), 117-146. http://dx.doi.org/10.1080/713600071

Lawrence, R. (1996). Single World, Divided Nations? Washington, DC: Brookings Institution Press and OECD Development Center.

Lheem, H. G., \& Guo, S. J. (2004, Spring). Political Economy of FDI and Economic Growth in China: A Longitudinal Test at Provincial Level. Journal of Chinese Political Science, 9(1). http://dx.doi.org/10.1007/BF02876956

Li, F., \& Min. (2005). Regional Inequality and Productivity Growth in China: The Role of Foreign Direct Investment, Infrastructure and Human Capital. New York.

Malaysia. (2001). Laporan Penyiasatan Buruh (Labor Research Report). Percetakan Nasional Malaysia Berhad.

Malaysia. (2005a). Jabatan Perangkaan Malaysia (Malaysian Statistics Department). Pencetakan Nasional Malaysia Berhad.

Malaysia. (2005b). Laporan Tahunan Bank Negara Malaysia (2005-2007) (Central bank annual report). Percetakan Nasional Berhad.

Malaysia. (2005c). Laporan Tahunan Perbadanan Kemajuan Industri Malaysia (2005-2007). Kuala Lumpur: Ministry of International Trade and Industry.

Malaysia. (2006). Rancangan Malaysia Kesembilan (2006-2010) (Ninth Malaysia Plan 2006-2010). Putrajaya: Unit Perancang Ekonomi, Jabatan Perdana Menteri (Economic Planning Unit, Prime Minister's Department).

Malaysia. (2011). Rancangan Malaysia Kesepuluh (2011-2015) (Malaysia Plan 2011-2015). Putrajaya: Unit Perancang Ekonomi, Jabatan Perdana Menteri (Economic Planning Unit, Prime Minister's Department).

Mazur, J. (2000). Labor's New Internationalism. Foreign Affairs, 81(1), 79-93. http://dx.doi.org/10.2307/20049615

MIDA. (2004, July 5). Malaysia - world's $5^{\text {th }}$. Most competitive country. Communication and Media Division MIDA.

MIDA. (2006). Annual Report Malaysian Industrial Development Authority (MIDA). Kuala Lumpur: Ministry of International Trade and Industry.

Nunnenkamp, P. (2004). To What Extent Can Foreign Direct Investment Help Achieve International Development Goals? The World Economy, 27(5), 657-677. http://dx.doi.org/10.1111/j.0378-5920.2004.00620.x

Pradhan, J. P. (2002). Foreign Direct Investment and Economic Growth in India: A Production Function Analysis. Indian Journal of Economics, 82(327), 582-586.

Prema-Chandra, A., \& Menon, J. (1996). "Export-led Industrialisation, Employment and Equity: Then Malaysian Case" Trade and Development 96/5. Australian National University, Department of Economics.

Rajendran, A. (2002). Malaysia: An overview of the legal framework for foreign direct investment. Economics and Finance, No. 5. ISEAS Document Delivery Service.

Rostam, K. (2001). Dasar dan strategi petempatan dalam pembangunan negara (Policy and strategy for settelements in national development). Bangi: Penerbit UKM.

Rostam, K. (2006). Pembandaran dan perkembangan Wilayah Metropolitan Lanjutan Lembah Klang-Langat, Malaysia. Jurnal e-Bangi, 1(1) 1-27.

Sun, H., \& Chai, J. (1996). Direct foreign investment and inter-regional economic disparity in China. International Journal of Social Economics, 25(2-4). 
United Nations Conference on Trade and Development (UNCTAD). (2001). World Investment Report 2001. United Nations, New York.

United Nations Conference on Trade and Development (UNCTAD). (2003). World Investment Report 2003. New York: United Nations.

Zhang, X., \& Zhang, K. H. (2003). How Does Globalization Affect Regional Inequality within a Developing Country? Evidence from China. Journal of Development Studies, 39(4), 47-57. http://dx.doi.org/10.1080/713869425

\section{Copyrights}

Copyright for this article is retained by the author(s), with first publication rights granted to the journal.

This is an open-access article distributed under the terms and conditions of the Creative Commons Attribution license (http://creativecommons.org/licenses/by/3.0/). 